\title{
Chronicity and primary care: The role of prison health
}

\author{
R Morral-Parente
}

Catalan Health Institute

\begin{abstract}
The Prison Primary Health Care Teams in Catalonia have been integrated into the Catalan Health Institute. This integration shall facilitate 1 training and updating, while eliminating the existing differences between the health services belonging to prison institutions and those of the Catalan Health Service.

It shall enable team work and coordination between Primary Health Care Teams in the community and the PHCTs in prisons within the same geographical area by sharing ongoing training, multi-sector work teams and territory-based relations, thereby facilitating continuance in care and complete and integrated treatment of chronicity.

The existing information systems in Primary Health Care and the shared clinical history in Catalonia are key factors for this follow up process.

Support tools for clinical decision making shall also be shared, which shall contribute towards an increase in quality and clinical safety. These tools include electronic clinical practice guides, therapeutic guides, prescription alert systems, etc.

This shall be an opportunity for Prison Health Care Teams to engage in teaching and research, which in turn shall have an indirect effect on improvements in health care quality and the training of professionals in this sector.

The critical factor for success is the fact that a unique chronicity health care model shall be shared, where measures for health promotion prevention can be taken, along with multi-sector monitoring of pathologies and with health care information shared between professionals and levels throughout the patient's life, both in and out of the prison environment.
\end{abstract}

Key words: Prisons; Primary Health Care; Primary Prevention; Chronic Disease; Labor Relations; Quality of Health Care; Spain; Health Services.

Text received: 01/20/2015

Text accepted: 05/23/2015

It has been eleven long years ever since May 28th 2003 when Act 16/2003 on the Cohesion and Quality of the National Health System was published, establishing that prison health services were to be transferred to the corresponding autonomic health departments. After all, this integration has become a reality in Catalonia since October 2014.

So what does this integration mean for prison health?

Prison health in Catalonia is now part of the Catalan Health Service (SCS). More specifically: prison primary care teams have been integrated into the Catalan Health Institute. This fact entails new perspectives and challenges for medical practitioners developing their tasks in such services. Professionally, this integration will facilitate their training and updating and previous labor differences between prison health services and the
Catalan Health Service will be overcome. However, the fundamental turning point implies the approach and management of those citizens who at some point have been deprived of their liberty and who, once the sentence has been served, come back and continue being assisted by community primary care services.

Prevention programs are of paramount importance within the penitentiary setting ${ }^{2}$ for several reasons. First, because for some inmates such programs represent their first contact with medical services. Second, because particular lifestyles and living in society entail the need for early detection of certain contagious diseases which are more prevalent in prison, such as tuberculosis. Moreover, health promotion and prevention programs are also crucial as far as health and hygiene habits are concerned. Once outside prison, tracking and monitoring these patients by 
the primary care network in a cross-sectional coordinated way is fundamental to ensure continuous care. In the near future, this integration will enable a crosssectional comprehensive approach of chronicity.

Greater life expectancy together with an increased survival of individuals with chronic diseases as well as the availability of better care contributes to an ageing population $^{3}$ and to an increased number of people who suffer from chronic diseases. This represents a major challenge as far as organizing and providing medical care to this group is concerned.

According to the Ministry of the Interior, in prisons the main causes of mortality in 2011 were first cardiovascular diseases (which accounted for 19.5\% of the total number of deaths) and second digestive complications arising from cirrhosis $(10.7 \%)$, followed by respiratory $(7.4 \%)$ and oncologic diseases $(6.7 \%)$. Not so very long ago, the main cause of death was derived from the infection by the Human Immunodeficiency Virus (HIV). Today, only $6 \%$ of deaths in prison are due to HIV.

Further, average age among inmates has also risen and thus the prevalence of chronic diseases, as in the general population.

In 2011 in Catalonia, the Department of Health defined the 2011-2015 Health Plan as a reference for future health policies. It was then when the Chronicity Prevention and Care Program ${ }^{5}$ was created to lead all strategic measures taken in terms of chronic diseases. This Health Plan outlines the relevant role of Primary Care in the prevention, detection, control and proactive monitoring of chronicity (see Figure 1).

The Health Department chronicity program is based on certain strategic pillars which include the implementation of integrated clinical processes, strengthening health protection, promotion and prevention programs, encouraging patients and caregivers taking responsibility of their health and promoting self-healing and the implementation of regional care programs for complex chronic patients (see Figure 2).

In order to carry out this chronicity care program in prisons the role and involvement of prison primary care teams is crucial. Therefore understanding the reality and prevalence of main chronic diseases in prison is of paramount importance since such disorders act as an "iceberg" in these settings. According to some publications $^{6-7}, 19.7 \%$ of inmates had a diagnosis of some type of chronic disease as opposed to $32.3 \%$ who had no previous diagnosis yet fulfilled criteria for some disease. Accordingly, proactive early detection of risk factors and hidden diagnosis are a priority.

Already existing information systems in Primary Care (Figure 3) and the implementation of electronic clinical records are going to be the centerpieces for this matter. Currently these tools are fundamental in recording structured clinical information and sharing

\section{1-2015 Health Plan}

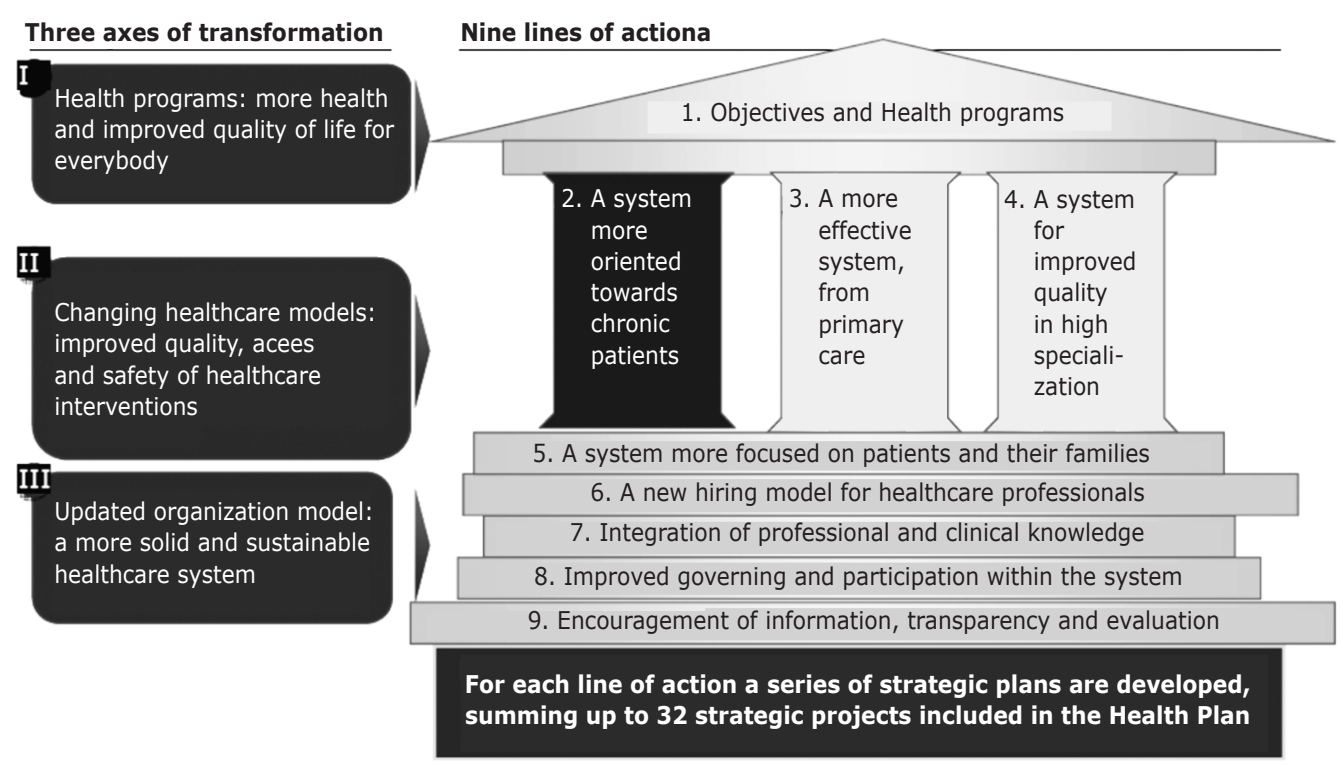

Figure 1: Source: 2011-2015 Catalan Health Plan, Health Department. Catalonia 2015. 


\section{Strategic lines within the Chronicity Plan}

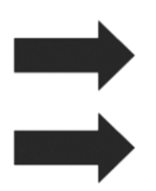

\subsection{Implementing integrated clinical processes}

2.2. Strengthening health protection, promotion and prevention programs

2.3. Encouraging patients and caregivers taking

0) responsibility of their health and promoting self-healing

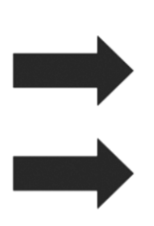

2.4. Developing healthcare alternatives within an integrated system

2.5. Implementing regional care programs for complex chronic patients

2.6. Implementing programs for the rational use of drugs
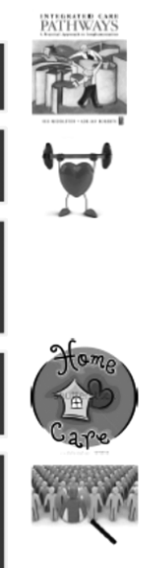

\section{Generalitat}

de Catalunya

PROGRAMA PREVENCIÓ I ATENCIÓ A LA CRONICITAT

Figure 2: Source: 2011-2015 Catalan Health Plan, Health Department. Catalonia 2015.

\section{SICAP: Information system for professionals}

\begin{tabular}{|c|c|c|c|c|c|c|c|c|c|c|}
\hline \multirow{2}{*}{ Indicador } & \multicolumn{5}{|c|}{ Professional } & \multirow{2}{*}{$\begin{array}{l}\text { Màxim } \\
\text { Punts }\end{array}$} & \multicolumn{2}{|c|}{ Metes } & \multicolumn{2}{|c|}{ Resultats de l'entorn } \\
\hline & Prevalença & Detecció & Resolució & Resultat & Punts & & Minim & Màxim & EAP & ICS \\
\hline 05-AVC: Tractament antiagregant & $1,48 \%$ & $78,26 \%$ & $95,83 \%$ & $93,75 \%$ & 10 & 10 & 75,36 & 92,93 & $89.25 \%$ & $90,74 \%$ \\
\hline (1) 06-AVC: Control lipídic & $1.48 \%$ & $78,26 \%$ & $54.17 \%$ & $52,99 \%$ & 50 & 50 & 37.17 & 49,24 & $53.65 \%$ & $48.13 \%$ \\
\hline 07-Cl. Tractament beta-bloquejant & $2,46 \%$ & $88,96 \%$ & $42,5 \%$ & $42,5 \%$ & o & 10 & 48.39 & 62,91 & $46.79 \%$ & $59.18 \%$ \\
\hline (1) 08-Ct. Tractament antiagregant & $2,46 \%$ & $88,96 \%$ & $92,5 \%$ & $92,5 \%$ & 9,43 & 10 & 73,42 & 93,66 & $77,92 \%$ & $85,92 \%$ \\
\hline (1) 09-Cl: Control lipídic & $2,46 \%$ & $88,96 \%$ & $72,5 \%$ & $72,5 \%$ & 50 & 50 & 43,41 & 55,56 & $55,05 \%$ & $52,04 \%$ \\
\hline (1) 10-Dislipèmia: Càlcul RCV (35-74a) & $26,94 \%$ & $100 \%$ & $88,08 \%$ & $\mathbf{8 8 , 0 8 \%}$ & 65 & 65 & 62,27 & 84,97 & $86,06 \%$ & $80,02 \%$ \\
\hline (1) 11-ACXFA: Tractament AAS /ACO & $1,97 \%$ & $100 \%$ & $62,5 \%$ & $62,5 \%$ & o & 10 & 63,28 & 80,98 & $57,99 \%$ & $76,71 \%$ \\
\hline (1) (12-HTA: Control TA & $20,18 \%$ & $95,54 \%$ & $63,41 \%$ & $63,41 \%$ & 90 & 90 & 54,59 & 62,48 & $60,16 \%$ & $63,17 \%$ \\
\hline (1) 13-HTA: Control TA en població de risc & $10,65 \%$ & $91,72 \%$ & $63,58 \%$ & $63,58 \%$ & 60 & 60 & 43,16 & 51,57 & $53,29 \%$ & $55,42 \%$ \\
\hline D O 14-IC: Tractament IECA / ARAll & $1,17 \%$ & $87,81 \%$ & $68,42 \%$ & $68,42 \%$ & $\mathbf{7 , 7 1}$ & 10 & 51,86 & 73,33 & $61,79 \%$ & $65,07 \%$ \\
\hline (1) (1) 15-IC: Tractament beta-bloquejant & $1,17 \%$ & $87.81 \%$ & $31,58 \%$ & $31,58 \%$ & 0 & 10 & 33,78 & 49,07 & $32,35 \%$ & $45,81 \%$ \\
\hline (1) 17-Alcohol: Cribratge (15-79a) & & & & $37,56 \%$ & 19,32 & 65 & 34,35 & 45,14 & $39.14 \%$ & $39.53 \%$ \\
\hline (1) (18-Tabac: Abstinents en població de risc & $26.46 \%$ & $93.75 \%$ & $80.23 \%$ & $80,23 \%$ & 55 & 55 & 65.82 & 75,71 & $71,31 \%$ & $71,09 \%$ \\
\hline (1) (-) 19-Tabac: Cessacions en els darrers $12 \mathrm{~m}$ (15-79a) & $16.77 \%$ & $100 \%$ & $7.09 \%$ & $7,09 \%$ & 52,26 & 70 & 5,59 & 7,6 & $7,36 \%$ & $6.18 \%$ \\
\hline (1) 20 -DM2: Cribratge peu & $7,69 \%$ & $100 \%$ & $64 \%$ & $64 \%$ & 45 & 45 & 49 & 61,67 & $59,41 \%$ & $56.48 \%$ \\
\hline (1) 21-DM2: Control HBA1C (15-79a) & $6,67 \%$ & $100 \%$ & $63,37 \%$ & $63,37 \%$ & 60 & 60 & 48,47 & 59,03 & $57,09 \%$ & $57,72 \%$ \\
\hline (1) 22-DM2: Cribratge retinopatia (15-79a) & $6,67 \%$ & $100 \%$ & $92,08 \%$ & $92,08 \%$ & 45 & 45 & 55,04 & 70,14 & $73,9 \%$ & $66,5 \%$ \\
\hline (1) 29-Grip: Vacunació ( $>59 a)$ & & & & $48,64 \%$ & o & 60 & 50 & 60 & $45,66 \%$ & $51,38 \%$ \\
\hline (1) 30-Grip: Vacunació població de risc (15-59a) & $7,82 \%$ & $87,18 \%$ & $24,21 \%$ & $24,21 \%$ & 39,92 & 45 & 18 & 25 & $15,92 \%$ & $18,66 \%$ \\
\hline
\end{tabular}

Screen for the visualization of indicators by clinicians and nurses. Monthly information

Figure 3: Source: SICAP, Catalan Health Institute. 
all the resources involved in taking decisions, as well as in the monitoring of all chronic and acute pathologies.

Among the already existing resources in Primary Care it is worth highlighting the role of clinical practice guides and therapeutic prescription guides in electronic form, alert systems as far as different aspects of prescription are concerned (Prefaseg and Selaudit) , the development of active knowledge systems in clinical medical records (ECAP), laboratory alerts, common protocols, access to Catalan Shared Clinical Records (HCCC) in which all care providers publish records on complementary tests, hospital discharges, emergencies, etc. All in all, a series of support tools for clinicians, which encourage clinical safety and quality. This monitoring and evaluation system counts upon evidence based indicators and objectives to allow clinicians identify patients who, for some reason, are not achieving target objectives and carry out evolutionary control of their health issues.

The integration of both information systems and professionals themselves will encourage team work and coordination between different prison and community primary health teams. Regional shared continuing training, cross-sectional work teams and coordination and relationship mechanisms are some of the tools to achieve this.

Teaching is another pillar of Primary Care. Currently there are 74 accredited teaching centres within the Catalan Health Institute 8 , including $75 \%$ of the available positions for Family and Community Medicine and Nursing specialized health care training, with over 750 residents trained every year. This will entail the opportunity for prison primary health teams to become involved in teaching, which will indirectly improve quality healthcare and training of professionals.

As far as research is regarded, Primary Care counts upon its own Research Institute (Jordi Gol Primary Care Research Institute). This acts a methodological reference for research projects and teams. It plays a significant role in promoting the development of cross-sectional research projects.

The key to success will be sharing a sole proactive model of care for chronic diseases which includes health promotion and prevention measures and cross-sectional monitoring of chronic diseases and an information system common to all practitioners and all services involved in the provision of care to citizens, whether imprisoned or not.

\section{CORRESPONDENCE}

Rosa Morral Parente

Institut Català de la Salut (Catalan Health Institute)

Gran Via de les Corts Catalanes, 587, 3a planta

08007 Barcelona

\section{BIBLIOGRAPHICAL REFERENCE}

1. García-Vidal J. Ser médico de familia en la cárcel. AMF 2014; 10(11) 676-8.

2. Melguizo M. De la enfermedad crónica al paciente en situación de cronicidad. Aten Prim 2011; 43: 67-8.

3. Serrano MD. Derecho a la salud de los internos en centros penitenciarios y sanidad penitenciaria (II). Revista de Derecho UNED; 2010; 7: 525-60.

4. Coordinación de Sanidad Penitenciaria de la Secretaría General de Instituciones Penitenciarias. Mortalidad en Instituciones Penitenciarias 2011. Madrid: Ministerio del Interior del Gobierno de España; 2012.

5. Contel JC, Muntané B, Camp L. La atención al paciente crónico en situación de complejidad: el reto de construir un escenario de atención integrada. Aten Pimaria 2012; 44: 107-13.

6. Rosen R, Trust N, Ham C. Integrated Care: lessons from evidence and experience [Internet]. London: The Nuffield Trust; 2008 [cited 2015 Jan 20]. Available from: http://www.nuffieldtrust. org.uk/publications/integrated-care-lessons-evidence- and-experience.

7. Vera-Remartínez EJ, Borraz-Fernández JR, Domínguez-Zamorano JA, Mora-Parra LM, Casado-Hoces SV, González-Gómez JA, et al. Prevalencia de patologías crónicas y factores de riesgo en población penitenciaria española. Rev Esp Sanid Penit 2014; 16: 38-47.

8. Memoria 2013. Barcelona: Institut Català de la Salut; 2014. 